\title{
CORAL REEF REHABILITATION IN THE SALEH BAY, WEST NUSA TENGGARA
}

\author{
Sri Turni Hartati ${ }^{1)}$, Didik Wahju Hendro Tjahjo's, and Awwaluddin ${ }^{3)}$ \\ 1) Researcher at Research Center for Fisheries Management and Conservation, Ancol-Jakarta \\ 2) Researcher at Research Institute for Fish Stock Enhancement, Jatiluhur-Purwakarta \\ 3) Researcher at Research Institute for Marine Fisheries, Muara Baru-Jakarta \\ Received July 10-2009; Received in revised form April 1-2010; Accepted February 16-2011
}

\begin{abstract}
The covering area damages noted up to the year of 2000 for the Western Saleh Bay's coral reefs were ranged from 48.24-66.37\%. A domain introduced to recover the coral damages in Saleh Bay waters was habitat enhancement by using an artificial reef technology. To identify possible successes in the habitat, enhancement project was conducted during the year 2004 and 2006. The objectives of this study were (1) to identify the progress of coral reefs rehabilitation scheme and (2) to estimate the succession rate of coral reef rehabilitation. Data collection consisted of oceanography parameters, coral healthy, fish community, and sessile organisms. The results showed that Bila Cape waters of Rakit Island and Ganteng Island waters in Saleh Bay were appropriate to be the candidates of coastal rehabilitee areas. During 2004-2006 some progresses of the both selected areas significantly noted for fish community and sessile organisms as such as changes in species numbers and diversity index. The study recommended a capacity expanding of artificial reef areas as wide as $55.600 \mathrm{~m}^{2}$ for 115 unit modules in the Bila Cape waters and $6.504 \mathrm{~m}^{2}$ for 46 unit modules in the Ganteng Island. The artificial reef will give more benefits as well as the economical value if it is constructed up to $400 \mathrm{~m}^{3}$.
\end{abstract}

KEYWORDS: $\quad$ habitat enhancements, coral reefs, coral fishes, artificial reefs, Saleh Bay, West Nusa Tenggara

\section{INTRODUCTION}

Indonesia has about $85,700 \mathrm{~km}^{2}$ in area of coral reefs or $14 \%$ of the whole coral reefs in the world (Nontji, 2002). The location of the coral reefs mostly closes in marginal community settlement. Actually, the coral reef waters have supported fishery industries and well being of fishers for long time; however, at present the majority of reef areas have already degraded. The human activities of economic developments lead to tremendous strain on coral reefs. Sukarno et al. (1983) confirmed that cyanide fishing, blast fishing, and coral exploiting were major sources of coral dwelling in Indonesia. For this reason, most coral reef ecosystems lost their functions as well as losses of production, genetics, protection, shelters, niches, nurseries, and spawning grounds.

The dwindling coral reefs dispersed on some regional reef areas of Indonesia waters, especially in the west region. Finding of LIPI's studies in 1996 (Dahuri, 2000) showed that around $40 \%$ of coral damages was due to natural and anthropogenic alterations. The damages extensively increased in intensity into $70 \%$ in a year of 2000 . Only $28 \%$ was addressed to the well coral reefs (KPP-COREMAP, 2001).

Based on local fishermen notes, coral reefs in shallow waters of Saleh Bay have already been damages due to uses of destructive fishing gears. Percent covers of dead corals at southern coastal area of Saleh Bay ranged from 48.24-66.37\% (Marasabessy \& Abdul, 2001). Those included in a typical category of coral damages (Soekarno et al., 1983).

Cesar (1997) explained that economical losses were derived directly from coral exploitations. A net profit of each kilometer square for coral exploitation will get USD \$121,000; unfortunately it will make some losses for social incomes (US $\$ 93,600$ ), for fishery industries (ranged from US\$12,000-260,000), for coastal area protection (ranged from US $\$ 2,900$ 481,900 ), for tourism opportunities (US $\$ 67,000$ ), and other unpredictable losses as well as nutrient, genetic, and biodiversity values.

Respecting of the last condition of coral reefs, one of decision makings for general coral reef managements struggled to establish guideline by making protected areas, restoration areas, conservation zones, and habitat enhancement. One of mitigation measures of dwindling coral reefs were development of artificial reefs in the Jakarta Bay (19801988) and then continuing from 1990-1993 for some regions such as North Sumatera, Lampung, West Java, Central Java, East Java, and Bali. Some reports stated that the cement block artificial reefs successfully lead to positive impacts for expected 
outputs of biological, ecological, and economical purposes.

The positive progresses derived responses to keep on habitat enhancement project for other regions. The last project implementation of installing artificial reefs in 2005 has been placed in Saleh Bay of West Nusa Tenggara. The project activities included advance studying, artificial reef installing, and project monitoring that carried out from 2004-2006. This paper describes some outputs of the project activities as well as tentative area determinations and on going succession identifies of the rehabilitant waters after submerging artificial reefs.

\section{MATERIALS AND METHODS}

\section{Time and Location of the Study}

This study used two approaches; (1) determinations of the selected areas in order to seek for suitable positions for artificial reef placements. Those activities were carried out in 2004 by gathering some benchmark data and information. The selected areas placed at southern waters of the Saleh Bay; (2) identifications of any pioneer organisms coming and occupying the artificial reefs that have already submerged in 2005. Those well known as the new recruitments of marine biota, the fist succession process as well, that had been carried out in 2006 one year after the artificial reef submerging.

\section{Data Collections and Analyses}

Oceanography data collection included water depth, transparency, temperature, current, acidity, salinity, and dissolved oxygen. Those were measured by using a depth meter, secchi disk, current meter, and water checker kit.

Reef data collected by using a line intercept transect method. A global positioning system device were used to record geographical positions of the transect areas. A roll meter was used to measure lifeform objects being intercepted by the tape meter. The measurements were repetitively done for $30 \mathrm{~m}$ in 10 $m$ depth. Data of the intercepted life-forms were calculated to find out coral cover percentages (English et al., 1994).

A benthic life-form software that commonly recommended in ASEAN and Australia was used to get the coral cover percentages (Rahmat \& Yosephine, 2001). According to Chou (1998) coral reef health status referred to the percentage of the criteria based on the coverage of the hard corals. The criteria are excellent (>75\%), good (<75->50\%), fair (<50->25\%), and poor $(<25 \%)$.

Sessile organisms were obtained by identifying, counting and recording whatever biota attached and settled on the artificial reef surfaces. Data of coral fish were obtained by using the visual census on line transects with the $500 \mathrm{~m}^{2}$ census area (English et al., 1994). By using SCUBA equipment, an observer dived along fifty meter length of the line transects. The diver recorded all species found and individual numbers on waterproof sheets. Fish photograph guide books were used to identify the fish species (Kuiter, 1992; Lieske \& Myers, 1997).

Coral fishes were grouped into three categories showing their status, namely major species, target species, and indicator species (English et al., 1994). The major species are coral fishes that are usually found in coral reefs as a resident species. Target species are coral fishes that are caught for food and/ or sold by fishermen. The target species have also a great affinity to coral reefs as intruders. Indicator species are coral fishes that can be used in determining coral reef health. These include some ornamental fish belong to the family of Chaetodontidae.

The computed values of the reef fish on the study sites derived from the calculation of Shannon-Weaver Diversity Index $(H)$. Microsoft Excel software recommended by Ludwig \& Reynold (1988) was used in the analysis of data.

Formulas for calculating the indices are:

Shannon Weaver Diversity Index:

$\mathrm{H}=\Sigma\left\{(\mathrm{n} / \mathrm{N}) \ln \left(\mathrm{n}_{i} / \mathrm{N}\right)\right\}$

where:
$\mathrm{n}_{\mathrm{i}}=$ species number at $\mathrm{i}$
$\mathrm{N}=$ total of individual of entire species
$\mathrm{H}=$ Shannon Index

\section{RESULTS AND DISCCUSSION}

Tentative sites of artificial reef placement were Rakit Island, Lipan Island, Dompo Island, and Ganteng Island. Figure 1 shows the study sites and identified habitats for a reef health check. The results of coral reef health studies in those islands were described in Table 1 and 2. As the results, the Table 1 showed that the Bila Cape waters of Rakit Island was considered as an appropriate rehabilitee site by applying the 
artificial reef technology. This site had already damaged with the lowest percent cover of live corals including coral massive, coral sub massive, and coral branching. The reef plate lied in the shallow waters that have the highest percentage of dead corals and has a great number of rubbles. The bottom profile of Bila Cape of Rakit Island was showed in Figure 2. On the other hand, the waters of Kuncar and Tambora have a good level of percent covers of hard corals. Those are not appropriate to put into action of rehabilitating purposes. The other tentative sites consist of mangrove areas and sea grass beds, which will not be chosen in this rehabilitation program.

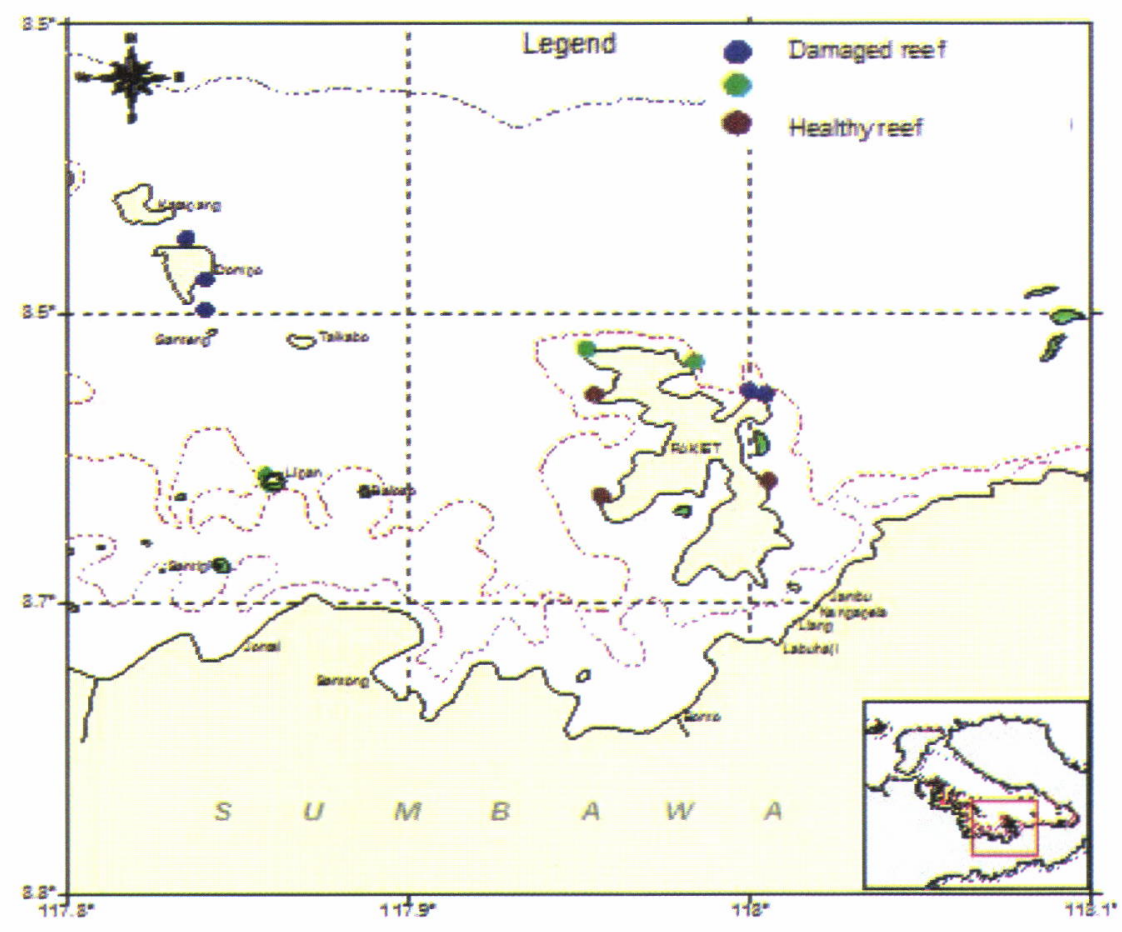

Figure 1. The study sites and health status of coral reefs.

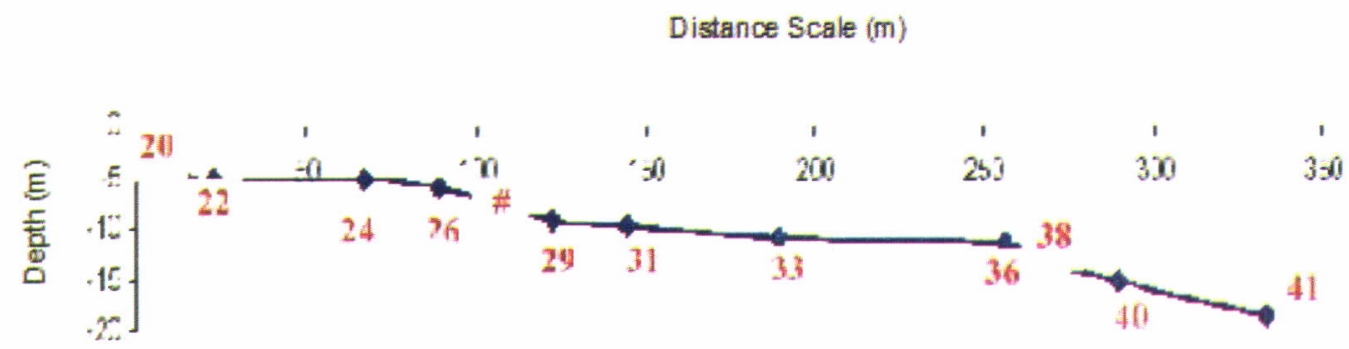

Figure 2. Sea bottom profile of Bila Cape waters, Rakit Island. 
Table 1. The coastal condition of Rakit Island, Saleh Bay, West Nusa Tenggara, in 2004

\begin{tabular}{|c|c|c|c|}
\hline Site names & Geographical position & Sea bottom categories & Existing coral species \\
\hline Bila Cape 1 & $\begin{array}{c}08^{\circ} 3736,7^{\prime \prime} \mathrm{S} \\
117^{\circ} 59^{\prime} 58,4^{\prime \prime} \mathrm{E}\end{array}$ & $\begin{array}{l}\text { Percent covers of live } \\
\text { corals }(20 \%) \text {, dead corals } \\
(75 \%), \text { soft coral }(5 \%) \text {, and } \\
\text { COT: Acanthaster planci } 1 \text { - } \\
10 \text { individuals }\end{array}$ & $\begin{array}{l}\text { Massive corals (Porites } \\
\text { lutea, Porites lobata), } \\
\text { Branching corals } \\
\text { (Palauastrea ramose, } \\
\text { Montipora ditata), and CS } \\
\text { (Porites rus) }\end{array}$ \\
\hline Bila Cape 2 & $\begin{array}{c}08^{\circ} 37^{\prime}, 40^{\prime \prime} \mathrm{S} \\
118^{\circ} 00^{\prime} 14,8^{\prime \prime} \mathrm{E}\end{array}$ & $\begin{array}{l}\text { Damaged coral reefs due to } \\
\text { blast fishings }\end{array}$ & low diversity \\
\hline Eastern Rakit Island & $\begin{array}{l}08^{\circ} 09^{\prime}, 27,5^{\prime \prime} \mathrm{S} \\
118^{\circ} 00^{\prime} 19^{\prime \prime} \mathrm{E}\end{array}$ & $\begin{array}{l}\text { The areas of mangrove and } \\
\text { Sea grass beds }\end{array}$ & - \\
\hline Kima Cape & $\begin{array}{l}08^{\circ} 39^{\prime}, 46,0^{\prime \prime} \mathrm{S} \\
117^{\circ} 57^{\prime} 22,6^{\prime \prime} \mathrm{E}\end{array}$ & $\begin{array}{l}\text { The areas of mangrove and } \\
\text { Sea grass beds }\end{array}$ & - \\
\hline Katumpang Cape & $\begin{array}{c}08^{\circ} 37,40^{\prime \prime} \mathrm{S} \\
117^{\circ} 57^{\prime} 14,9^{\prime \prime} \mathrm{E}\end{array}$ & $\begin{array}{l}\text { The areas of mangrove and } \\
\text { Sea grass beds }\end{array}$ & - \\
\hline Kuncar Cape & $\begin{array}{l}08^{\circ} 36,43,8^{\prime \prime} \mathrm{S} \\
117^{\circ} 57^{\prime} 06,3^{\prime \prime} \mathrm{E}\end{array}$ & $\begin{array}{l}\text { Percent covers of live } \\
\text { corals }(50 \%) \text {, dead corals } \\
(40 \%) \text {, and soft corals } \\
(10 \%) \text {, and COT: } \\
\text { Acanthaster planci } 1-10 \\
\text { individuals }\end{array}$ & $\begin{array}{l}\text { Massive corals (Porites } \\
\text { lutea, Porites lobata), } \\
\text { Branching corals } \\
\text { (Palauastrea ramose, } \\
\text { Montipora ditata) } \\
\text { Submassive Corals (Porites } \\
\text { rus), Branching Acropores } \\
\text { (Acropora sp.), and sponge. }\end{array}$ \\
\hline Tambora Cape & $\begin{array}{l}08^{\circ} 36,59,8^{\prime \prime} \mathrm{S} \\
117^{\circ} 59^{\prime} 00,8^{\prime \prime} \mathrm{E}\end{array}$ & $\begin{array}{l}\text { Percent covers of live } \\
\text { corals }(50 \%) \text {, dead corals } \\
(40 \%) \text {, soft coral }(10 \%), \\
\text { and COT: Acanthaster } \\
\text { planci } 1-10 \text { individuals }\end{array}$ & $\begin{array}{l}\text { Massive corals (Porites } \\
\text { lutea, Porites lobata, and } \\
\text { Branching corals), } \\
\text { (Palauastrea ramose, } \\
\text { Montipora ditata) } \\
\text { Submassive Corals (Porites } \\
\text { rus) }\end{array}$ \\
\hline
\end{tabular}

Table 2 indicated a good category for percent covers of hard corals in the Lipan Island. Base on the percentage of its coverage, massive corals were more dominant than that for sub massive corals, and branching corals. The corals growing in shallow waters with the depth ranged from 3-5 $\mathrm{m}$. The reef plates were not quite extensive in coverage. Unlike reefs of the Lipan Island, coral reefs in Dompo Island were found in serious damage. The coverage of live corals was only $5 \%$. The reef plate ranged of $50 \mathrm{~m}^{2}$ in areas and $7 \mathrm{~m}$ in depth.
Ganteng Island's coral reefs were also stated in a damaged category. The live coral coverage was less than $10 \%$. The hard corals, such as massive corals, sub massive corals and branching corals, shared growing with seagrases dominated area. The damaged reef plate was found extensively in this area. For this reason, the area will be appropriate for a location of rehabilitation purposes.Bottom profile of Ganteng Island was showed in Figure 3. 
Table 2. The coastal condition of the waters of Dompo, Ganteng, and Lipan, Saleh Bay, West Nusa Tenggara, in 2004

\begin{tabular}{|c|c|c|c|c|}
\hline Site names & $\begin{array}{l}\text { Geographical } \\
\text { position }\end{array}$ & Sea bottom categories & Coral species & Existing reef's status \\
\hline Dompo Island & $\begin{array}{c}08035^{\prime}, 276^{\prime \prime} \mathrm{S} \\
117050^{\prime}, 408^{\prime \prime} \mathrm{E}\end{array}$ & $\begin{array}{l}\text { Percent covers of live } \\
\text { corals }(5 \%) \text {, dead } \\
\text { corals/rubbles }(80 \%) \text {, } \\
\text { and silt }(15 \%)\end{array}$ & $\begin{array}{l}\text { Massive corals } \\
\text { (Porites sp.) }\end{array}$ & Damaged \\
\hline Ganteng Island & $\begin{array}{l}08034^{\prime}, 429^{\prime \prime} S \\
117050^{\prime} 071^{\prime \prime} E\end{array}$ & $\begin{array}{l}\text { Percent covers of live } \\
\text { corals }(10 \%) \text {, dead } \\
\text { corals/rubbles }(80 \%) \text {, } \\
\text { other fauna }(10 \%) \text {, some } \\
\text { individuals of } \\
\text { Acanthaster planci }\end{array}$ & $\begin{array}{l}\text { Massive corals }(P . \\
\text { lutea, } P \text {. lobata), } \\
\text { branching corals ( } P \text {. } \\
\text { ramose, M. ditata), } \\
\text { submassive corals ( } P \text {. } \\
\text { rus) }\end{array}$ & Damaged \\
\hline Lipan Island & $\begin{array}{c}\text { 08039'20,9" S } \\
117051^{\prime} 29,11^{\prime \prime} \mathrm{E}\end{array}$ & $\begin{array}{l}\text { Percent covers of live } \\
\text { corals }(40-52 \%)\end{array}$ & $\begin{array}{l}\text { Massive corals }(P \text {. } \\
\text { lutea, } P \text {. lobata, } P \text {. rus, } \\
\text { favia sp.), branching } \\
\text { corals }(P . \text { ramose, } M \text {. } \\
\text { digitata) }\end{array}$ & Healthy \\
\hline
\end{tabular}

Distance scale $(\mathrm{m})$

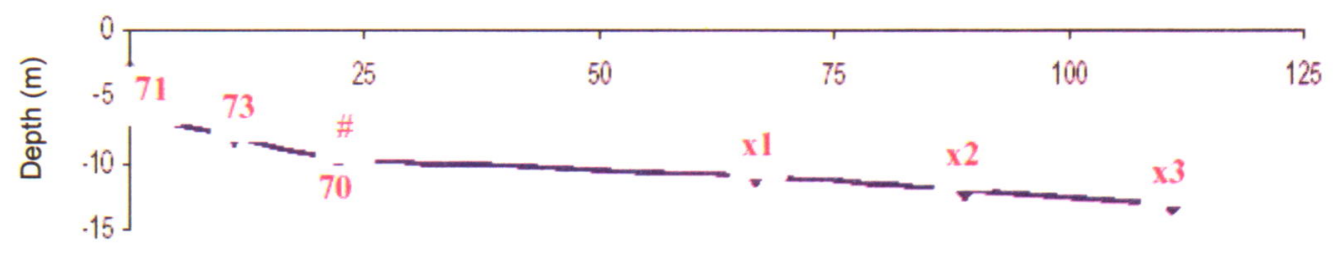

Figure 3. Sea bottom profile of Ganteng Island waters.

Table 3 shows the results of the oceanographic measurements. It presents water qualities of the study sites in which the water chemical and physical parameters would be suitable for a prerequisite location of enhancement habitat. Referring to the standard environmental qualities declared by the Central Government in terms of the 02-Living Environmental Regulation of 1988, the oceanography parameter values of water qualities of study sites were included in the regulation of threshold qualification for marine cultures, marine parks, conservation, and tourism activities.

The parameters were measured during the dry east monsoon. The oceanographic features of the Saleh Bay were influenced by solar radiation, geographical position, season, atmosphere exposure, adjacent waters, and lands. Water temperature, salinity, and dissolved oxygen are critical oceanographic parameters for the aquatic organisms.

Water transparency of the study areas were relatively clear and good, while those relatively poor were found in the adjacent waters of the Kima Cape and Eastern Rakit Island. These were due to runoff, siltation, mud-sandy bottom, and low coral covers. Vertical solar penetration in the study area was ranged from 5-10 m. Water temperatures of the study sites were warmer (above 27 Celsius), because shallow waters and high exposure to solar radiation. The current speed was relatively high and sufficient to distribute nutrients and remove the rubbishes from corals. Salinity in the study areas was relatively high $(34 \%)$ and more influenced the waters of the Banda Sea. Dissolved oxygen ranged from 3-4 ml/L. The acidity rates were typical for entire waters of the study areas. 
Table 3. Oceanography conditions of the selected areas of Saleh Bay waters, in October 2004

\begin{tabular}{|c|c|c|c|c|c|c|c|c|c|c|}
\hline Site names & Positions & $\mathrm{pH}$ & $\begin{array}{l}\text { Sal. } \\
\text { ( }\end{array}$ & $\begin{array}{c}\text { Terrp } \\
\text { (०) }\end{array}$ & $\begin{array}{l}\text { Current } \\
\text { Direct. } \\
\text { (\%) }\end{array}$ & $\begin{array}{l}\text { Current } \\
\text { speed } \\
\text { (cmidet) }\end{array}$ & $\begin{array}{c}\mathrm{DO} \\
(\mathrm{m} / \mathrm{L})\end{array}$ & $\begin{array}{l}\text { Trans } \\
\text { farency } \\
(\mathrm{m})\end{array}$ & $\begin{array}{l}\text { Depth } \\
\text { (m) }\end{array}$ & $\begin{array}{l}\text { Bottom } \\
\text { substrates }\end{array}$ \\
\hline Bila Cape 1 & $\begin{array}{c}08^{*} .37 .36 .7 \\
117^{*} .59 .58,4^{n} \mathrm{E}\end{array}$ & 8.00 & 34 & 27.6 & 260 & 3.01 & 3.94 & 10 & 10 & $\begin{array}{l}\text { Rubbles and } \\
\text { sand }\end{array}$ \\
\hline Bila Cape 2 & $\begin{array}{c}08^{=} \cdot 37 \cdot 40^{\prime \prime} \mathrm{S} \\
118^{\circ} .00^{\prime} \cdot 148^{\prime \prime} \mathrm{E}\end{array}$ & 8.01 & 34 & 27.82 & 220 & 0.67 & 3.33 & 9 & 10 & Sand \\
\hline $\begin{array}{l}\text { Eastern } \\
\text { Rakit Island }\end{array}$ & $\begin{array}{c}08^{\circ} .09^{\prime} .27 .5^{\prime \prime} \mathrm{S} \\
118^{\circ} 00^{\circ} .19^{\mathrm{m}} \mathrm{E}\end{array}$ & 7.94 & 34 & 28.06 & - & - & 3.91 & 7 & 10 & \multirow{2}{*}{$\begin{array}{l}\text { Shell } \\
\text { fragments } \\
\text { and sand } \\
\text { Sand }\end{array}$} \\
\hline Kima Cape & $\begin{array}{c}08^{*} \cdot 39^{\prime} \cdot 46.0^{\prime \prime} \mathrm{S} \\
117^{\prime} .57 \cdot 22.6^{\prime \prime} \mathrm{E}\end{array}$ & 7.50 & 34 & 27.4 & 360 & 2.56 & 3.81 & 5 & 5 & \\
\hline $\begin{array}{l}\text { Katumpang } \\
\text { Cape }\end{array}$ & $\begin{array}{r}08^{\circ}=37.40^{\circ} \mathrm{S} \\
117^{\circ}=57^{\prime} \cdot 14.9^{\circ} \mathrm{E}\end{array}$ & 7.89 & 34 & 27.45 & - & - & 3.81 & 8 & 11 & \multirow{3}{*}{$\begin{array}{l}\text { Shell } \\
\text { fragments } \\
\text { and sand } \\
\text { Shell } \\
\text { fragments } \\
\text { and sand } \\
\text { Rubbles }\end{array}$} \\
\hline $\begin{array}{l}\text { Kuncar } \\
\text { Cape }\end{array}$ & $\begin{array}{c}08^{*}: 36^{\prime} \cdot 43 \cdot 8^{\prime \prime} \mathrm{S} \\
117^{*}=57^{\prime} \cdot 06 \cdot 3^{77} \mathrm{E}\end{array}$ & 7.83 & 34 & 27.39 & 260 & 2.85 & 3.78 & 10 & 10 & \\
\hline Tambora & $\begin{array}{c}08^{*} .36^{\prime} .59 .8^{\prime \prime} 5 \\
117=59.00 .8^{\prime \prime} \mathrm{E}\end{array}$ & 8.02 & 35 & 27.74 & 180 & 4.16 & 3.75 & 10 & 15 & \\
\hline $\begin{array}{l}\text { Cape } \\
\text { Ganteng } \\
\text { Cape }\end{array}$ & $\begin{array}{l}08^{\prime} .34^{\prime} .11 .3^{n} 5 \\
117^{\prime} .50^{\circ} 07.1^{\prime \prime} \mathrm{E}\end{array}$ & 7.85 & 34 & 27.15 & 290 & 3.64 & 3.42 & 10 & 10 & \multirow{2}{*}{$\begin{array}{l}\text { Rubbles and } \\
\text { Sand } \\
\text { Rocks and } \\
\text { sand }\end{array}$} \\
\hline Lipan Cape & $\begin{array}{c}08: 39.31 .6^{\circ} \mathrm{S} \\
117^{:} .51 \cdot 32.7^{\mathrm{m}} \mathrm{E}\end{array}$ & 7.87 & 35 & 27.2 & 280 & 3.75 & 3.72 & 10 & 15 & \\
\hline
\end{tabular}

The First Succession of Pioneer Organisms in the Vicinity of the Artificial Reefs

In 2005, some units of a pyramid like articial reef were constructed from 80 units of hollowed concrete blocks with the volume $0.6 \times 0.6 \times 0.6 \mathrm{~m}$. Two units of pyramid were applied in each selected rehabilitee area. The whole process of making and setting were involving the local community to encourage them to protect the resources and its environment.

The first monitoring has been conducted in three months after submerging the artificial reefs at the selected areas of Rakit Island and Ganteng Island waters, especially in October 2005. The second monitoring for the fifteen month old artificial reefs was conducted in November 2005.

A coral fish visual census was carried out in the two selected areas, Rakit Island waters and Ganteng Island waters, where some artificial reefs were deployed. The calculated diversity index in the waters of Rakit island and Geteng island was $\mathrm{H}=1.21$ and $H=1.91$ respectively. According to Mason (1981) these indexes were categorized into low level criterium of species diversity. However, in 2006 the second monitoring activities carried out it was likely that the number of fish species found along the transect line was increased, with the increasing diversity index from
1.91-2.4 (Figure 4). These increases indicated by progress of sessile organism succession on artificial reef surfaces as well as by the changes in the fish community structure. The new recruitment of biota on cement blocks were to be significantly attractive to invite aggregating fishes, particularly the family of Apogonidae dominated the existing community. It's mean that all of fish population almost has the same opportunities to occupy the area available. During one year the fish species aggregating around the artificial reefs of both selected areas increased in amount from 31 and 39 specimen to 36 and 43 (Figure 5).

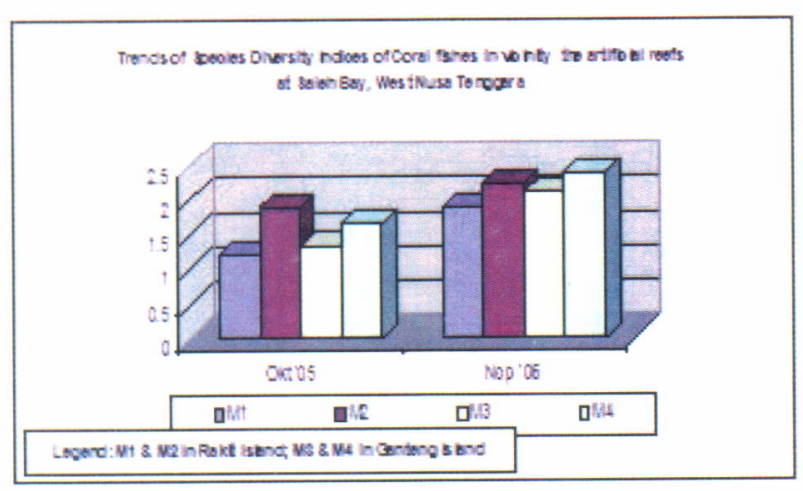

Figure 4. Coral fish species diversity index in the artificial reefs during 2005 and 2006. 
Trends of Fish Species Numbers in the Artificial Reefs

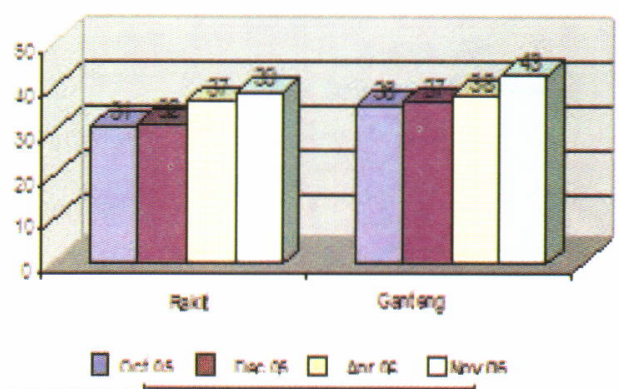

Figure 5. Increases in species numbers of coral fish during 2005 and 2006 in the vicinity the artificial reefs.

\section{Trend of Sessile Organism Growing}

In general, sessile organism growing on artificial reef surfaces provide a pioneer of community settlement as well as small fish schooling. Inventory results of the study indicated significantly a community growing increment of sessile biota. On the four sample modules of cement blocks, sessile organism colonization increased in number from 12$21,8-23,8-21$, and 9-27 colonies. Of the entire sample modules, sessile organism growing that has been successfully indentified were 16 species in October 2005 and increased to the amount of 37 in November 2006 (Figure 6). This progress of sessile community growing in the study areas was considered faster than that in artificial reef areas in Jakarta Bay in which within the $278^{\text {th }}$ day the identified sessile organism was only 11 species.

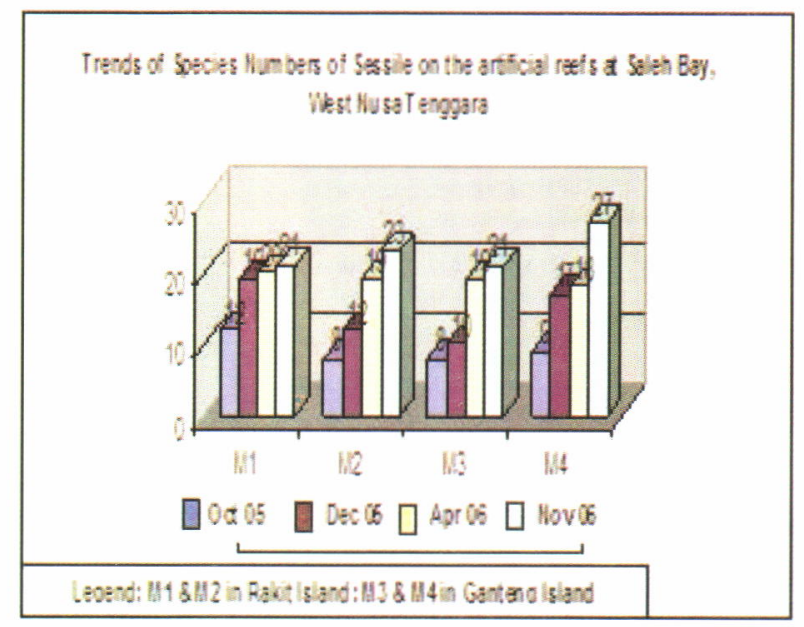

Figure 6. Species number increases of sessile organisms during 2005 and 2006 on the artificial reefs.
The dominant sessile organisms were algae (i.e. Enteromorpha sp. and Padina sp.), Ascidian (i.e. Polycarpa sp.), Antipatharian (i.e. Cirrhipathes sp. and Palythoa sp.), and Gastropod (i.e. Pinctada margaritifera and Pteria pinguin). Pioneers coral benthic life-forms were massive corals and branching corals.

\section{CONCLUSSION AND RECOMENDATION}

\section{Conclussion}

1. The waters of Bila Cape of the Eastern Rakit Island and Ganteng Island were selected to be the rehabilitee sites in Saleh Bay.

2. Some progresses of artificial reef submerging in the areas were found in the form of a positive trend in the number of fish species, increased in fish diversity index, and a significant growth of sessile organisms.

3. These progresses as well as the first level of ecological succession provide an initial indication of the successful marine ecological restoration.

\section{Recommendation}

The study recommended that the waters of Bila Cape and Ganteng Island possessing a capacity to expand the rehabilitee area through introducing an artificial reef technology as wide as $55.600 \mathrm{~m}^{2}$, and $6.504 \mathrm{~m}^{2}$ respectively. For the waters of Bila Cape, the needed artificial reef modules are 115 units, and for Ganteng Island are 46 units. The economical construction of the unit volume will be about $400 \mathrm{~m}^{3}$.

\section{ACKNOWLEDGEMENT}

This paper was part of the results of activities on the coral reefs resources development and habitat rehabilitation in the Saleh Bay, West Nusa Tenggara, F. Y. 2006, Research Institute for Fisheries Stock Enhancement, Jatiluhur-Purwakarta.

\section{REFERENCES}

Cesar, H. 1997. Nilai Ekonomi Terumbu Karang Indonesia. World Bank.

Chou, L. M. 1998. Status of Southeast Asian coral reefs. In Status of Coral Reefs of the World 1998. C. Wilkinson (Ed). Sida-Australian Institute of Marine Science-ICLARM Publ. Quensland. Australia. 
Dahuri, R. 2000. Kebijakan dan strategi pengelolaan terumbu karang Indonesia. Prosiding Lokakarya Pengelolaan dan Ilmu Pengetahuan dan Teknologi Terumbu Karang Indonesia. Lembaga IImu Pengetahuan Indonesia-COREMAP. Jakarta.

English, S., C. Wilkinson, \& V. Baker. 1994. Survey Manual for Tropical Marine Resources. Australian Institute of Marine Science. Townsville. Australia.

Kuiter, R. H. 1992. Tropical Reef Fishes of the Western Pacific Indonesia and Adjacent Waters. Gramedia. Jakarta.

KPP-COREMAP. 2001. Buku Panduan Pengelolaan Berbasis Masyarakat. Lembaga IImu Pengetahuan Indonesia (LIPI). Jakarta.

Ludwig, J. A. \& J. F. Reynolds. 1988. Statistical ecology. A Primer on Methods and Computing. Jhon Wiley \& Son. New York.

Lieske, E. \& R. Myers. 1997. Reef Fishes of the World. Periplus Edition. Jakarta. Indonesia.
Mason, C. F. 1981. Biology of Freshwater Pollution. Longman Scientific and Technical. Longman Singapore Publisher Ptc. Ltd. Singapore.

Marasabessy, M. D. \& H. Abdul. 2001. Kondisi Terumbu Karang di Perairan Teluk Saleh, Sumbawa Besar, Nusa Tenggara Barat. Pusat Penelitian dan Pengembangan Oseanografi. Lembaga Ilmu Pengetahuan Indonesia.

Nontji, A. 2002. Coral reefs of Indonesia. Prosiding Lokakarya Pengelolaan dan IImu Pengetahuan dan Teknologi Terumbu Karang Indonesia. Lembaga IImu Pengetahuan IndonesiaCOREMAP. Jakarta.

Rahmat \& Yosephine. 2001. Software Percent Cover Benthic Lifeform 5.1. Versi. Pusat Penelitian dan Pengembangan Oseanologi. Lembaga IImu Pengetahuan Indonesia. Jakarta.

Sukarno, M. Hutomo, M. K. Moosa, \& P. Darsono. 1983. Terumbu Karang di Indonesia: Sumber Daya. 